\title{
Law Activation Strategies (LAS) in Environmental Policymaking: a Social Mechanism for Re-politicization?
}

\section{Rémi Schweizer ${ }^{\mathrm{A}}$}

Despite the exponential development of environmental policies, environmental problems persist and are constantly evolving. There is, clearly, a distance between the abstraction of rules and the concreteness of action. Going beyond the depoliticization and institutional determinism that environmental policy analysis often conveys, this article suggests that the analysis should be re-politicized in order to understand these gaps. Based on this reasoning, the concept of "law activation strategy" (LAS) is proposed as a social mechanism to analyze the complex interplay between legal rules, actors' behaviors, and environmental outcomes. Embedded within political games and asymmetric power relations, LAS cover the various positions that actors may take with regards to the rules that structure their action: concretization, passivity, diversion, circumvention, and innovation. The concept is integrated to a broader analytical framework and applied to an empirical case study related to aquatic ecosystem protection in Switzerland. By doing so, the paper demonstrates the explanatory power of LAS and its pertinence in providing a more political understanding of environmental policymaking.

Keywords: environmental policy analysis, de-politicization, institutional determinism, actors and institutions, political games, law activation strategies

\section{Introduction}

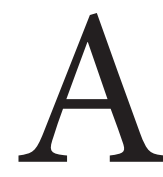
dried-out river at the height of summer, when withdrawals are at their maximum; a significantly and durably degraded ecosystem due to massive use of pesticides; an exceedingly high concentration of ozone and particles in a zone saturated with motorized transport: examples of human-caused environmental issues are with no end. Despite the exponential development of environmental policies since the 1970s (Knoepfel 1992), these issues not only persist, but are constantly progressing (e.g., Gleick et al. 2009; IPCC 2014). Discourses have evolved, legal rules have been adopted, and considerable efforts have been engaged without, however, producing the expected impacts. Clearly, the question arises as how to explain these gaps between rules and concrete situations on the field.

At least three perspectives have been mobilized in the environmental policy literature in order to explain these gaps. The most recent standpoint-subsumed here under the generic label of

\footnotetext{
${ }^{A}$ Institute of Political, Historical and International Studies (IEPHI), University of Lausanne, Switzerland
} 
environmental governance (Jordan, Wurzel, and Zito 2003; Lemos and Agrawal 2006)-focuses on the "wicked" nature of environmental problems, the new equilibrium between state and non-state actors, and the necessity to move beyond traditional forms of government. Traditional top-down instruments are perceived as inappropriate to address such issues and changes in the nature of environmental policies are proposed. A second perspective deals with the factors that may disturb a straightforward, effective implementation (implementation studies, which date back to Pressman and Wildavsky 1973). Focusing on existing policies, this approach generally proposes recommendations to increase goal compliance. The institutional analysis and development (IAD) framework developed by Ostrom and her colleagues represents the third prominent approach. Rooted in rational choice institutionalism (Ostrom 2007a), its application generally results in deductive models of individual decision making, on the basis of which predictions about environmental outcomes and/or institutional design principles are proposed.

Although they shed light on relevant dimensions and drivers of the policy process, the three above-described perspectives can be criticized for not fully accounting for the political dimension of environmental policymaking. Implementation is commonly assumed and the fact that actors may decide to adopt strategies of diversion, circumvention, or passivity with regards to the rules that structure their action is rarely referred to. Although they focus on the interplay between institutions (including legal rules), actors, and environmental outcomes, these approaches share a form of institutional determinism (Radaelli, Dente, and Dossi
2012). They leave underspecified the social mechanisms (Hedström and Ylikoski 2010) through which institutions shape actors' behaviors and see their influence on environmental outcomes mediated.

Yet in environmental policy as in other policy areas, it is clear from the point of view of various disciplines that courses of action rarely follow mechanically the paths set out by legal rules. Seminal approaches from sociology (e.g., Crozier and Friedberg 1977; Bourdieu 1990; Lascoumes 1990) and policy analysis (e.g., Scharpf 1997; Jessop 2001; Knoepfel et al. 2011; Lubell 2013) have emphasized the complex interplay between rules and actors. The latter should not be seen as the empty recipients of prescriptions they are eager to bring into life in the real world. Quite the contrary, actors necessarily need, for a given rule to produce its effects, to translate its abstract provisions at the level of action. Far from being mechanistic or linear, this process is highly political.

Bridging these various approaches, the present article assumes that the gaps between legal rules and environmental outcomes are the result of political processes, within which actors adopt competing strategies with regards to the rules that structure their action (i.e., competing law activation strategies, $L A S$ ). These $L A S$ represent, in other words, a conceptual attempt to unfold the social mechanisms through which the influence of legal rules on environmental outcomes is mediated. A three-step argumentation is provided in order to evaluate this assumption. The first part identifies two limitations that are common to most environmental governance, implementation, and IAD-related approaches: an evacuation of politics (leading to the de-politicization of envi- 
ronmental stakes) and an assumption of implementation (leading to institutional determinism). Building on these shortcomings, a re-politicization of environmental policy analysis is argued for. This will be done in the second part, which develops the notion of LAS as a crucial mechanism linking legal rules to environmental outcomes. LAS describe the strategies by which actors select the rules and modalities of activation they perceive as the most appropriate to reach their objectives. Reflections around the conceptual roots of LAS as well as an analytical framework aiming to understand their effects on environmental outcomes are proposed. The framework is, in a third part, applied to a case study on aquatic ecosystem protection in the Swiss Alps. Finally, the explanatory power of the framework is discussed and avenues for future research are proposed.

\section{Environmental policy analysis: to- ward a re-politicization}

\section{Environmental Governance approaches}

$\mathrm{T}$ he dominant perspective among policy scholars seems to be, nowadays, to explain the persistence of environmental problems by insisting on the inappropriateness of existing policies. Schematically, the reasoning proceeds as follows. Environmental problems are, in the first step, presented as wicked and uncommonly difficult to tackle with traditional policy instruments (Levin et al. 2012). Keys to this viewpoint are the allegedly ambivalence, uncertainty and complexity of environmental problems, and the myopic nature of environmental policies in that respect (Varone et al. 2013). At the light of these facts, drastic changes in the nature of environmental policies are promoted, and a vast array of approaches proposed: social resilience (Adger 2000), adaptive co-management (Olsson, Folke, and Hahn 2004), transition management (Kemp, Loorbach, and Rotmans 2007), network governance (Carlsson and Sandström 2008), collaborative governance (Ansell and Gash 2008), etc.

Pivotal to these approaches is a focus on the "good" design of policies. Echoing broader trends emphasizing the emergence of an era of governance (Rhodes 1997), policy instruments that differ from the state-centered, "command and control" perspective are identified and called for (Jordan, Wurzel, and Zito 2003). If environmental governance is as varied in form as ubiquitous in spread (Lemos and Agrawal 2006), it generally sees flexibility, collaboration, and social learning as well suited to handle environmental pressures. Emphasis is put on the ways social actors can cooperate, learn, and adapt together; and on the design of policy instruments that will favor such endeavors. By doing so, these approaches bring in "new sites, new actors, and new themes" (Hajer and Wagenaar 2003, 3) and provide several relevant theories "for understanding changing processes of governing" (Stoker $1998,18)$. The bulk of these studies also perpetrate, however, two tendencies that are problematic when it comes to the political understanding of environmental policymaking.

They are, firstly, characterized by an evacuation of politics that leaves them oblivious to dynamics of power, conflicts, and bargaining (Hornborg 2009; Offe 2009). Not only are power relations not fully accounted for, but "the nasty and dark side of the political that may disturb 
rational problem solving" is also blocked out (Voss and Bornemann 2011, 7). A presumption of consensus is widespread and the fact that actors may pursue diverging interests and may not be willing to cooperate or learn together is, to a large extent, put aside. By doing so, the environmental governance perspective participates to a de-politicization of environmental questions that is also present in political discourses or mainstream media (Swyngedouw 2009; Kenis and Lievens 2014). Because somehow we are all concerned, environmental politics is supposed to have translated into a form of political consensus.

An assumption of implementation is, secondly, largely widespread. It consists in assuming that new policy instruments will be implemented without providing any insights on the process through which this implementation will occur. The leitmotiv has been to insist on good policy design without much consideration for what happens afterwards. How the innovative instruments that are proposed should translate into environmental outcomes remains, to a wide extent, unexplored (see Jordan and Huitema 2014, who recently undertook to fill this gap). This shortcoming sometime comes with a "trivialization of obstacles to implementation" (Hornborg 2009, 252) and can also be referred to as "the promise of new modes of governance" (Bäckstrand $e t$ al. 2010).

\section{Implementation studies}

Policy implementation scholars provide a second, although somehow outof-fashion (Hupe 2014), perspective to explore the persistence of environmental problems. Focusing on the "missing link"
(Hargrove 1975), the "gap" (Dunsire 1978) between legal expectations and concrete realizations, they explore the processes that have to be gone through to turn rules into action. By doing so, these scholars certainly contributed to open "the black box of policymaking" (Palumbo and Calista 1990, 14). Formerly considered as purely mechanical, the "implementation stage" became a research object in its own right, leading to a wide and eclectic range of frameworks, theories, and models (Winter 2012; Hill and Hupe 2014). On some level however, it can be argued that the "link is still missing" (Robichau and Lynn 2009, 22). The way implementation studies have developed prevented them, in particular, to fully grasp the political dimension of policy processes. Most implementation studies share, more specifically, the two tendencies already outlined above with regards to environmental governance approaches.

On the one hand, although an implementation perspective should have contributed to bring "politics back into policy analysis" (Schofield 2001, 247), most studies seem to have reduced this political dimension to the smallest share. Implementation studies have often been practiced as a "governing-elite phenomenon" (deLeon and deLeon 2002, 468), looking at what should happen (and what is preventing it from happening) rather than at what is actually happening. The orientation is straightforward and topdown (Hupe 2011) and the bottom-up challenge that emerged in the 80s (Barrett and Fudge 1981; Hjern and Hull 1982) generally ignored. From the beginning, these studies have sought to highlight "the numbers of factors that may adversely affect implementation" (Ingram 1990, 465). The focus is on the ambiguity of pol- 
icy goals, the number of decision points or the quality of leadership instead of on power relations, diverging interests, and other actorial dimensions. This emphasis on factors rather than on actors contributed to hide the political realities of policies and to create an artificial "separation between politics and administration" (Barrett 2004, 254).

An assumption of implementation is, secondly, largely widespread. It consists in assuming that once a rule is adopted, "actors are raring to go and implement" (Schofield 2001, 259). Frequently framed in managerialist terms, implementation studies consider action mainly as a problem of transmission and application of legislative provisions decided at the top (Barrett and Fudge 1981, 4). The fact that actors may ignore what to do or decide to adopt strategies of diversion, circumvention, or passivity is largely ignored. The focus is on "goal compliance" (Winter 2012) and a rather pessimistic tone is widespread.

Rational choice institutionalism and the IAD framework

The IAD framework (Ostrom 2007a) represents a third prominent approach that has been employed to study the relationship between institutions, actors, and environmental outcomes. Harmonious with most environmental governance theories (some of them being explicitly grounded in the framework), broader and more systematic than implementation studies, it has been widely-and fruitfully-applied to analyze environmental politics. Rooted in rational choice institutionalism, the framework focuses on a given action arena, composed of a specific set of actors located within a specific ac- tion situation (described in terms of positions, actions, access to information, etc.). These actors are affected by several external variables (including "rules in use") and enter in patterns of interactions that generate diverging environmental outcomes.

By contrast to the two above-mentioned approaches, the IAD framework and some of its emanations-e.g., common-pool resources (CPR) theoriesstrongly focus on actors' actions and interactions when explaining environmental outcomes. As some have already reasoned (e.g., Dupuis and Knoepfel 2015), however, it appears necessary to depart from some assumptions that the framework perpetrates in order to fully understand the political nature of environmental policymaking. These assumptions consist, again, in two trends: toward de-politicization and toward institutional determinism.

The framework largely omits, in line with most rational choice approaches, the role of asymmetric power relations and conflicting interests in environmental politics (Clement 2010; Dupuis and Knoepfel 2015). Adopting the premises of positivism and methodological individualism (Johnson 2004), it relies on deductive models of individual decision making in order to propose design principles for more robust institutions. It fails, by doing so, to consider the power dynamics and the plurality of beliefs and interests at work. Those are not necessarily ignored but, clearly, maintained at the periphery of the analysis. Take for instance the CPR theories: they offer a view of local communities as homogenous and a-conflictual when, in reality, these communities represent arenas of competitions, inequalities, and exclusion (Johnson 2004; Schweizer 2013). 
Institutions are, as a result, mainly considered as structures of cooperation. The framework perpetrates an instrumental view (Sondershaus and Moss 2014) that does not tell much about institutions as structures-and stakes-of power (Moe 2005). This particular approach to institutions results in a tendency to exaggerate their explanatory power and to consider well-designed institutions as panaceas (Ostrom 2007b), producing causal reductionism (Dupuis and Knoepfel 2015) and institutional determinism (Radaelli, Dente, and Dossi 2012). The role of actors in the use of the law is, as a result, largely downplayed. Rules are considered as "outside the possibility of actors to use them in a differentiated way" (Radaelli, Dente, and Dossi 2012, 546) and an assumption of implementation is, again, widespread.

\section{A need for re-politicization}

All three perspectives convey, in sum, an oblivion of power dynamics and an assumption of implementation that lead to a form of institutional determinism. In spite of their (common) goal of analyzing the interplay between institutions, actors, and environmental outcomes, these approaches fail to provide a thorough view of the mechanisms through which institutions shape actors' behaviors and see their effects on environmental outcomes mediated. To the contrary, they contribute to feed the myth of an apolitical form of policies, technocratic and orientated by rational problem solving (deLeon 1994). They echo what Torgerson (1986) framed as the "first face" of policy analysis, characterized by the old "dream of the abolition of politics-of putting an end to the strife and confusion of human society in favor of an orderly administration of things based upon objective knowledge" (p. 34). Environmental policymaking, because it is legitimated by a supposed political consensus (Swyngedouw 2009) and because nature is often represented as "external to the social" (Kenis and Lievens 2014, 538), is particularly exposed to this risk.

The present paper makes the assumption that, to the contrary, environmental policy analysis should be re-politicized in order to understand the complex processes through which legal rules impinge on actors' behaviors and environmental outcomes. Rather than ignoring the political dimension of policymaking, it is argued that environmental policy analysis would benefit from paying more attention to power relations, diverging interests and strategies, and other actorial variables that are at the core of these processes. Institutions affect reality only because actors mediate and materialize their effects in their day-to-day interactions. They are not just "abstract entities" (Peters 2011, 38), but complex webs of constraints and opportunities.

Environmental policymaking should, in that sense, be considered as a circular and continuous process of normative creation (Lascoumes 1990). It is political "through and through", with every step being the "outcome of political give and take" (Wagenaar 2015, 248). In that respect, the implementation of rules is as challenging as their adoption. It does not represent a common quest to reach the best possible outcome but, to the contrary, a contested scene where competing rationalities, interests, and strategies may arise. In the end, the outcomes that will be reached depend on the configuration of the involved actors, on the nature of their power relations, and, last but not least, on what these actors actually do (i.e., on the strategies they pursue). 
Following that line of thought, the paper argues that policy scholars' contribution to the understanding of environmental policymaking should lie in the systematic account of these actorial driving forces, in general, and of the social mechanisms through which institutions shape actors' behaviors and environmental outcomes, in particular. A focus on the strategies that actors pursue with regards to the legal rules that structure their action (LAS, see below) is seen as particularly relevant. It supposes, first, to put the political side of environmental policymaking at the center of the analysis, and second, to break off with institutional determinism by going beyond the widespread assumption of implementation.

\section{Law activation strategies within political games}

(LAS)

$\int$ is n the following sections, a framework is proposed around the concept of LAS. The goal is to provide a political frame of intelligibility to understand why and how gaps between legal rules and environmental outcomes emerge. The analytical framework and its basic assumptions are presented in a first step. Then the conceptual roots of LAS are detailed and a typology is proposed. Finally, the implications of LAS for environmental outcomes are apprehended through the concept of local regulatory arrangements (LRA).

\section{Basic assumptions and broad analytical framework}

The explanatory scheme adopted in the framework is not causal, but actorial (Berthelot 1990). Rather than on direct causal explanations, the focus is on the di- versity of variables and social mechanisms that play a role in understanding the interplay between legal rules, actors' behaviors, and environmental outcomes. The framework relies, more precisely, on three basic assumptions that converge to place the notion of LAS at its center.

First, in line with bottom-up implementation scholars, the policy-action relationship is regarded "as a process of interaction and negotiation" (Barrett and Fudge 1981, 21). Rather than by a given formal rule, actors are bound together by a specific environmental problem that only some of them want to solve (Hjern and Hull 1982). It is, therefore, the problem as socially constructed that represents the starting point of their action. The problem in question is not an objective and expert-based phenomenon; rather, it is based on subjective perceptions of the reality (Scharpf 1997) an alleged risk of water or air pollution; a site seen as contaminated; a resource perceived as over-exploited-and involves trade-offs between competing interests.

Institutions are, second, considered as important elements of context (Peters 2011). In political systems based on the rule of law, the legal rules adopted by public authorities represent a particularly important institutional corpus (Gerber et al. 2009). If, however, policy designs (i.e., public law) certainly matter in explaining why and how changes happen, their explanatory power should not be overestimated. They represent only one of the bodies of law that influence environmental collective action. Constitutional rules, as well as private law (e.g., property rights regimes) also play an important role (Schlager and Ostrom 1992). In fact, environmental problems are affected by an ever increasing mass of rules that are not necessarily consistent (Gerber et al. 2009). 
There is always, in addition, a scope for maneuver (Bourdieu 1990; Jessop 2001) for implementing agents and social actors. Formal law acts as a set of constraints and opportunities that shape actors' behaviors, restraining action without determining it. On the one hand, rules impinge on social processes by affecting actors' perceptions and preferences (Scharpf 1997), by attributing action resources (Knoepfel et al. 2011), and by favoring specific courses of action. On the other hand however, they do not influence outcomes mechanically but represent a system of potentialities for the involved actors (Lascoumes 1990). Public as well as social actors can very well activate rules strategically (Aubin 2008), as "weapons" (Bourdieu 1990, 91) to impose their worldviews. The concept of law activation refers to such strategic behaviors.

Actors bound by a specific problem and evolving within a specific frame of institutions engage-it is the third assumption-in complex social processes. Developed in various approaches from political science (Scharpf 1997; Knoepfel et al. 2011; Lubell 2013) and sociology (Crozier and Friedberg 1977; Bourdieu 1990), the idea of political games is put at the center of the analysis. It serves as a "master metaphor" (Bardach 1977, 56) that provides a "frame of attention and interpretation" (Scharpf 1997, 7) to account for actors' interactions, actions, and power relations (Crozier and Friedberg 1977, 113). It is, as such, necessarily politically loaded. Concretely, the game image supposes to decompose the processes of policymaking into three elements: the actors' configuration (which actors are playing and how do they interact?); their power relations (which cards do they hold?); and, finally, the strategies they are pursuing (which cards do they play? Are they trying to cheat, to play in creative ways?).

The analytical framework that arises from these assumptions is summarized in Figure 1. LAS are, in sum, developed with regards to a socially constructed environmental problem, shaped by a specific context of institutional constraints and opportunities, and embedded within political games. Analytically, they represent a social mechanism (Hedström and Ylikoski 2010) through which institutions shape actors' behaviors. They materialize in LRA (see below) and, in the end, contribute to influence environmental outcomes.

\section{Law activation as a strategy}

The notion of strategy has been developed by various strands of literature, from strategic analysis (Crozier and Friedberg 1977) and intentional explanation (Korpi 1985) to critical sociology (Bourdieu 1990; Lamaison and Bourdieu 1986), actor-centered institutionalism (Scharpf 1997) or strategic-relational approaches (Jessop 2001; Hay 2002). Bridging these contributions, a strategy is defined here as the intentional conduct by which actors evaluate, select and constantly adapt the course of their action to their environment, and to the behaviors of other actors. It describes, in other words, the way actors mobilize their power and their context of action in order to influence a policy process. Five constitutive elements stem from this definition. A strategy supposes an intention, a selection (between potential courses of action), a dynamic (of anticipation and adaptation), an interaction (with other actors' strategies), and an environment (within which it is to occur). These dimensions and their theoretical roots and implications are detailed in Table 1. 


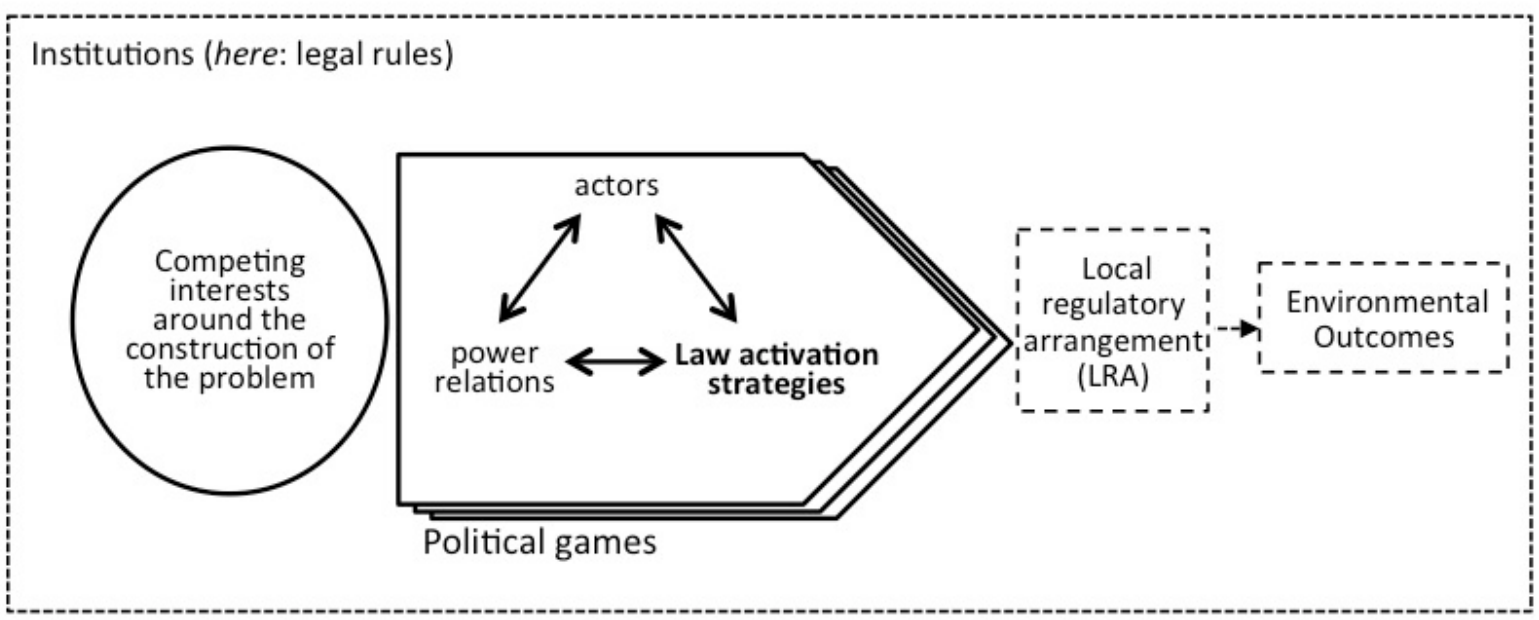

Figure 1 Broad analytical framework around LAS

Building on that train of thoughts, law activation is considered as strategic because it implies the intentional selection of rules and modalities of activation in order to reach an objective, as well as the adaptation of the selected strategies in the course of political games. The strategic activation of rules is to be considered as a crucial dimension of actors' actions in political systems based on the rule of law, where legal rules are continuously aggregated. These rules are, in real-world processes, subject of innumerable negotiations around the forms of their implementation; some are not even activated, and others may very well be explicitly bypassed or diverted.

Following Bourdieu (1990, 91), LAS can be seen as a continuum going from strict and rigid implementation to plain and clear transgression. The scope of possible LAS will, however, always depend on the subjective perceptions of the actor: some may perceive a scope for maneuver, while other may fill a strong (e.g., social, cultural, or religious) pressure toward implementation. The choice will also be contingent on the other actors involved and on their respective strategic capacity (see Table 1). In an effort of systematization, Table 2 proposes five ideal types of LAS: passivity, concretization, diversion, circumvention, and innovation. These ideal types represent a proposition drawn from the literature (see the references in Table 2) and from empirical studies and discussions conducted within the research group "Resources and Institutional Regimes"

Local regulatory arrangement (LRA) and environmental outcomes

LAS are considered as central mechanisms to understand how legal rules translate into environmental outcomes. In a given empirical situation, the selected LAS will interact and be re-

\footnotetext{
${ }^{1}$ This research group was constituted in the frame of doctoral seminars that gathered, between 2009 and 2013, Ph.D. students and senior researchers from Swiss Universities that were working on environmental issues in Switzerland and other parts of the world (France, Indonesia, India).
} 
Table 1 Constitutive dimensions of a strategy

\begin{tabular}{|c|c|}
\hline Intention & $\begin{array}{l}\text { Strategies are the deeds of intentional actors, which choose to act in ways } \\
\text { they believe to be means to their goals (Korpi 1985). A strategy is } \\
\text { motivated by "the intention to realize certain outcomes and objectives" } \\
\text { (Hay 2002, 129). It has a sense for the actor adopting it, because of more } \\
\text { or less ambiguous and contradictory intentions, preferences, and } \\
\text { motivations. Intentionality does not, however, concur with (economic) } \\
\text { assumptions of omniscience or rational calculation. To the contrary, the } \\
\text { notion applies indifferently to (hypothetically) rational and totally erratic } \\
\text { behaviors (Crozier and Friedberg 1977). }\end{array}$ \\
\hline Selection & $\begin{array}{l}\text { Intentional actors make (more or less) conscious choices (Korpi 1985) in } \\
\text { order to reach their objectives. A strategy is seen, in that sense, as } \\
\text { involving a selection between potential (Hay 2002, 129) or feasible } \\
\text { (Scharpf } 1997,73 \text { ) courses of action. }\end{array}$ \\
\hline Dynamic & $\begin{array}{l}\text { Strategies are not frozen in time but constantly evolve to adapt to the } \\
\text { perceptions, beliefs, and anticipations of the actor pursuing it. Actors' } \\
\text { preferences are, as well as their selected courses of action, constantly } \\
\text { reviewed, revised, and reformed (Hay 2002). Intentions are not fixed, and } \\
\text { actors may adjust their strategy to unforeseen events or to other actors' } \\
\text { behaviors. }\end{array}$ \\
\hline Interaction & $\begin{array}{l}\text { Strategies are intrinsically relational, "interactive" as Scharpf }(1997,36) \\
\text { putted it. They are linked to the action of other actors and, as such, are } \\
\text { indivisible from dynamics of power and domination. They fall within } \\
\text { complex webs of power, within which actors do not have an equivalent } \\
\text { strategic capacity (Crozier and Friedberg 1977). }\end{array}$ \\
\hline Environment & $\begin{array}{l}\text { Strategies are always situated-territorially, socially, and institutionally. } \\
\text { They do not arise from decontextualized, hyper-rational agent, but from } \\
\text { social actors embedded within specific environments or social structures } \\
\text { (Korpi 1985; Crozier and Friedberg 1977; Jessop 2001). These actors } \\
\text { operate, in particular, "within institutional settings that, at the same time, } \\
\text { enable and constrain these strategies" (Scharpf 1997, 36). Institutions are, } \\
\text { in other words, both internalized and strategically weighed by actors. }\end{array}$ \\
\hline
\end{tabular}


Table 2 Five ideal types of LAS

\begin{tabular}{|c|l|}
\hline Passivity & $\begin{array}{l}\text { Strategy by which an actor chooses (or is constrained) not to act, that is } \\
\text { not to activate or refer to a given rule (strategy of non-decision, } \\
\text { Bachrach and Baratz 1963). }\end{array}$ \\
\hline Concretization & $\begin{array}{l}\text { Strategy by which an actor seeks to implement a rule as closely as } \\
\text { possible to its formulation and its intent (i.e., strategy of } \\
\text { implementation). }\end{array}$ \\
\hline Diversion & $\begin{array}{l}\text { Strategy by which an actor seeks to activate a rule to other ends than } \\
\text { what the rule is intended for (Lascoumes 1990, 56). }\end{array}$ \\
\hline Innovation & $\begin{array}{l}\text { Strategy by which an actor resists to the implementation of a given rule, } \\
\text { either by invoking another rule (confrontation, Aubin 2011) or by } \\
\text { assuming that its behavior will not be punished (circumvention "en } \\
\text { règle", Bourdieu 1986). }\end{array}$ \\
\hline $\begin{array}{l}\text { Strategy by which an actor seeks to develop an ad hoc, tailor-made } \\
\text { solutions to address an environmental issue on the ground, going } \\
\text { beyond what is provided for in legal rules. }\end{array}$ \\
\hline
\end{tabular}

fined in the course of political processes of negotiation and bargaining. In the end, some actors will manage to impose their view and the process will (temporarily) come to an end. An "arrangement" will be reached that will "regulate" the issue with regards to the "local" situation at stake-hence the term of local regulatory arrangement.

LRA represent, in other words, the output of actors' games. Their ambition is not to solve the environmental problem but rather to close the political games initiated around it. Bringing together a variety of policy decisions (authorizations, sanctions, court decisions) or private agreements (contracts, oral agreements), LRA materialize a (temporary) consensus around the problem. They are more or less coercive and necessarily discrim- inating, favoring the strategic orientation of one of the actors involved in the game. Depending on the strategic orientation that prevails, LRA will be more or less favorable in terms of environmental protection. They will result in the implementation, diversion, circumvention, or development of legal rules and, as such, materialize a gap between these rules and environmental outcomes.

\section{LAS in action: an empirical illus- tration}

7 he following sections illustrate the empirical relevance of the concept 1 of LAS through the "thick analysis" (Adger et al. 2003) of a case study. A "case" is defined as a bounded empirical phenomenon composed of "complex 
configurations of events and structures" (Ragin 2000, 57). In casu, the case is delineated by the environmental policymaking process related to the issue of aquatic ecosystem protection in Valais (Switzerland). This case was selected because it deals with a situation where there is a clear and recognized gap between a formal rule (obligation to remediate watercourses in order to protect aquatic ecosystem) and an incongruent environmental outcome (no change in water flows and ecosystem protection). It represents, therefore, an original empirical contribution that is of particular interest to study the interplay between legal rules, actors' behaviors, and environmental outcomes.

The case study traces the social process (Hall 2008) and mechanisms (Hedström and Ylikoski 2010) by which this environmental outcome occurred. The framework developed in Figure 1 around the notion of LAS is applied. It directs toward a three-folded research protocol: (1) competing interests around the construction of the problem; (2) political games and LAS; (3) LRA and environmental outcomes. The following sections are organized according to this protocol, which also orientated data collection and interpretation.

Data collection involved a politico-legal screening of media and official documents (legislation, reports from the administration, actors' statements). In addition, field visits to local withdrawals and about 15 in-depth semi-structured interviews were conducted between 2011 and 2013 with representatives of cantonal services, local authorities, and social actors. The relevant actors were identified by using a snowball sampling approach (Patton 1990), i.e., by progressively constructing the sample through the networks and relations of previous interviewees. These sources were then analyzed and triangulated in order to confront the divergences between actors and produce a sound and precise reconstruction of the processes at play. An intermediary case study report was also submitted to the interviewees in order to validate, enrich, and/or qualify the findings.

Competing interests around the construction of the problem

Water is a resource whose economic importance is crucial for the canton of Valais, which is situated at the heart of the Alps, around the Rhône upstream river basin. Both the Rhône and its tributary watercourses provide a wide range of services to the population: many sources are used for drinking water; withdrawals for irrigation have been operated for centuries and are protected by a rare form of private water rights (immemorial water rights); and an impressive number of concessions for hydropower production have been granted since the adoption of the federal Water Rights Act (WRA) in 1916. These human activities have tremendous implications for the living environment that water represents for plants and animals, which has been under both qualitative (increased pollution levels) and quantitative (insufficient residual flows) threats (Federal Council 1987). In Valais, it is not rare for watercourses to see their flow substantially reduced. Even in a place often depicted as the water tower of Europe, a dried-out river can be a reality.

Switzerland revised its Water Protection Act (WPA) in 1991 in order to protect aquatic ecosystem from such situations. All substantially affected watercourses should have been remediated by 
cantonal authorities before 2012 (art. 80 WPA, which leaves some flexibility as to the exact nature and extent of the remediation measures). Yet, in Valais, nothing has changed (Federal Office for the Environment, 2013). Clearly, the revision of the WPA did not lead to a political consensus around the problem. To the contrary, its recognition has met-and continues to meet-strong competing interests.

On the one hand, the WPA certainly contributed to put the problem on the political agenda by forcing the cantonal administration to do "something" - at least to take position. The issue is also recognized by social actors on the ground, in particular by environmental nongovernmental organizations (NGOs) and fishermen associations. On the other hand, aquatic ecosystem protection faces strong competing interests. Hydropower production enjoys, first, a positive image. It represents a safe and green source of energy, benefiting from a strong political consensus at the federal and cantonal levels-even more in a context where Switzerland decided, in 2011, to withdraw progressively from the use of nuclear energy. In parallel, irrigation represents another important water use. Specific to the Valais with regards to their economic and symbolic importance (traditional water channels-bisses-are considered as part of the cantonal heritage), irrigation withdrawals are numerous in lateral watercourses (Federal Office for Agriculture 2007).

\section{Political games and LAS}

The processes that arose around the issue of aquatic ecosystem protection are indivisible from these complex trade- offs. They took place both within and at the margin of an inter-services working group established by the cantonal administration in order to elaborate a consensual remediation plan. The different interests at play were reproduced in the conflicting views of the cantonal services that were invited to take part to this working group: the service of environmental protection (SPE), the service of energy and hydropower forces (SEFH), and the service of agriculture (SCA). Each pursued what they claimed to be the prevailing public interest, and promoted it by adopting what was perceived as the most appropriate and legitimate LAS. In parallel, social actors that shared the same interests (environmental NGOs and fishermen associations, hydropower companies, and farming associations) have been more or less active in promoting their worldviews, in parallel or in close collaboration with these services. The three groups of actors that emerged from this specific configuration, as well as the LAS they pursued, are described below:

Environment: the SPE took an active part to the inter-services working group. It promoted the implementation of strong remediation measures, in line with the requirements of the WPA. The goal was to reach a satisfying level of protection for aquatic ecosystem by requiring minimal water flows downstream of important withdrawals (measures of water endowments). The LAS adopted by the SPE was one of concretization of the WPA. However, because the SPE was politically isolated and lacked the resources to pursue its strategy (in terms of personal, political support, and information about the withdrawals), it faced difficulties to impose its view within the inter-services working group. 
In parallel, environmental NGOs and fishermen associations pursued a similar strategy, although more offensively. They orientated their actions around two axes: communication in the media (focusing on the impacts of hydropower production) in order to re-affirm the importance of the issue and to maintain some level of social pressure; and, when it was clear that the remediation measures that had been adopted would be insufficient, judicialization of the policymaking processes through the activation of their right to appeal (granted by art. 55 of the federal Environment Protection Act, EPA).

Energy: the SEFH played a key role. It drove and coordinated the inter-services working group and, by doing so, controlled both the timing of the procedure and the technical information needed for the elaboration of remediation measures. The goal it pursued was two-folded. First, it is apparent that the service aimed at delaying the implementation of the WPA, in particular through the elaboration of a complex web of intermediary policy decisions (a directive in 2002, a remediation plan in 2008, and numerous feasibility studies and intermediary reports). Second, it pushed toward weak remediation measures in order to avoid a loss of production for hydropower companies (measures of coordination, construction, or exploitation rather than measures requiring specific water endowments). In the pursuit of this strategy, the SEFH worked in close collaboration with hydropower companies, which were for instance responsible for mandating and financing feasibility studies.

Totally congruent with the politically supported view in the canton, this course of action can be qualified as a LAS of minimal concretization. The SEFH did not try to resist openly to the implementation of remediation measures (which would have constituted a LAS of circumvention), but sought to reduce their impacts by profiting from the flexibility that the WPA let to cantonal authorities with regards to the nature of the remediation measures.

Agriculture: the SCA refused to participate in the inter-services working group. It argued that irrigation withdrawals should be given absolute priority over other water uses (including living environment) for three main reasons: their destination (food production), their legal protection ("immemorial water rights", recognized by the Swiss Civil Code), and their allegedly low impacts on watercourses. According to this interpretation, remediation measures were not applicable to irrigation and the service was not required to take part in their elaboration.

By doing so, the SCA pursued a LAS of circumvention by confrontation, i.e. by invoking another formal rule. In more details, the service resisted to the implementation of the WPA by claiming the absolute priority of immemorial water rights. This interpretation is, however, inconsistent with the dominant and legally approved definition, which considers unambiguously that irrigation withdrawals are also subject to remediation measures (Largey 2013). Although this strategy did not beneficiate from the support of other actors, it was never frontally put into question. The SCA managed to take benefit from the complex implementation context and from the over-mediatization of hydropower production to put irrigation at the second level. As a result, other agricultural circles never felt the need to act and could remain out of the game (LAS of passivity). 


\section{LRA and environmental outcomes}

The LRA that emerged from this specific configuration of actors, power relations, and LAS are structured into two phases. In a first time (t1), the LRA was largely congruent with the dominant strategy of minimal concretization promoted by the SEFH. A cantonal remediation plan was adopted in 2008 , but it contained very few measures of water endowments. Several feasibility studies were conducted by hydropower companies, and validated through a series of intermediary decisions. At the end of the implementation period (December 2012), however, only 12 final decisions had been adopted and a single one had actually been executed. Practically nothing had changed on the ground (both for hydropower and irrigation withdrawals); ecosystem protection had not been improved (absence of environmental outcomes).

In a second time however ( $\mathrm{t} 2$ ), following the legal appeals of environmental NGOs (11 out of the 12 final decisions had been attacked), the whole implementation scheme was put into question. Two judgments from the Valais cantonal court, inspired by a verdict of the Swiss federal court concerning another canton, were adopted in November and December 2012. The cantonal court estimated that the prescribed remediation measures were not ambitious enough and, more particularly, that measures of water endowment were to be favored (Largey 2013).

These judgments forced the cantonal authorities to review the up-to-then favored strategy. An internal document produced by the SEFH in March 2013 took note of the decisions and proposed to adapt the remediation plan. The policymaking process entered, in other words, in a new phase that was not investigated as part of this case study.

\section{Discussion and Conclusion}

Contributions to environmental policy analysis

The framework developed in the
present research proved to be a
powerful tool to understand how a specific set of legal rules and LAS, a conflicting social construction of the problem and a subtle repertoire of political games interacted to produce a questionable outcome in terms of environmental protection. Figure 2 offers a synthetic representation of the interplay between these variables.

This process represents a classical example of implementation deficit, where a clear gap is observed between a legal rule (art. $80 \mathrm{WPA}$ ) and an outcome. In such a case, most environmental governance scholars would have highlighted the necessity to move beyond traditional forms of government by designing more collaborative or flexible policy instruments. As for implementation scholars, their attention would have been on increasing goal compliance by identifying what should have happened and the administrative factors that prevented it from happening. IAD-related approaches, finally, would have provided deductive models of individual decision making and developed principles for a better institutional design.

This process represents a classical example of implementation deficit, where a clear gap is observed between a legal rule (art. $80 \mathrm{WPA}$ ) and an outcome. In such a case, most environmental governance scholars would have highlighted the ne- 


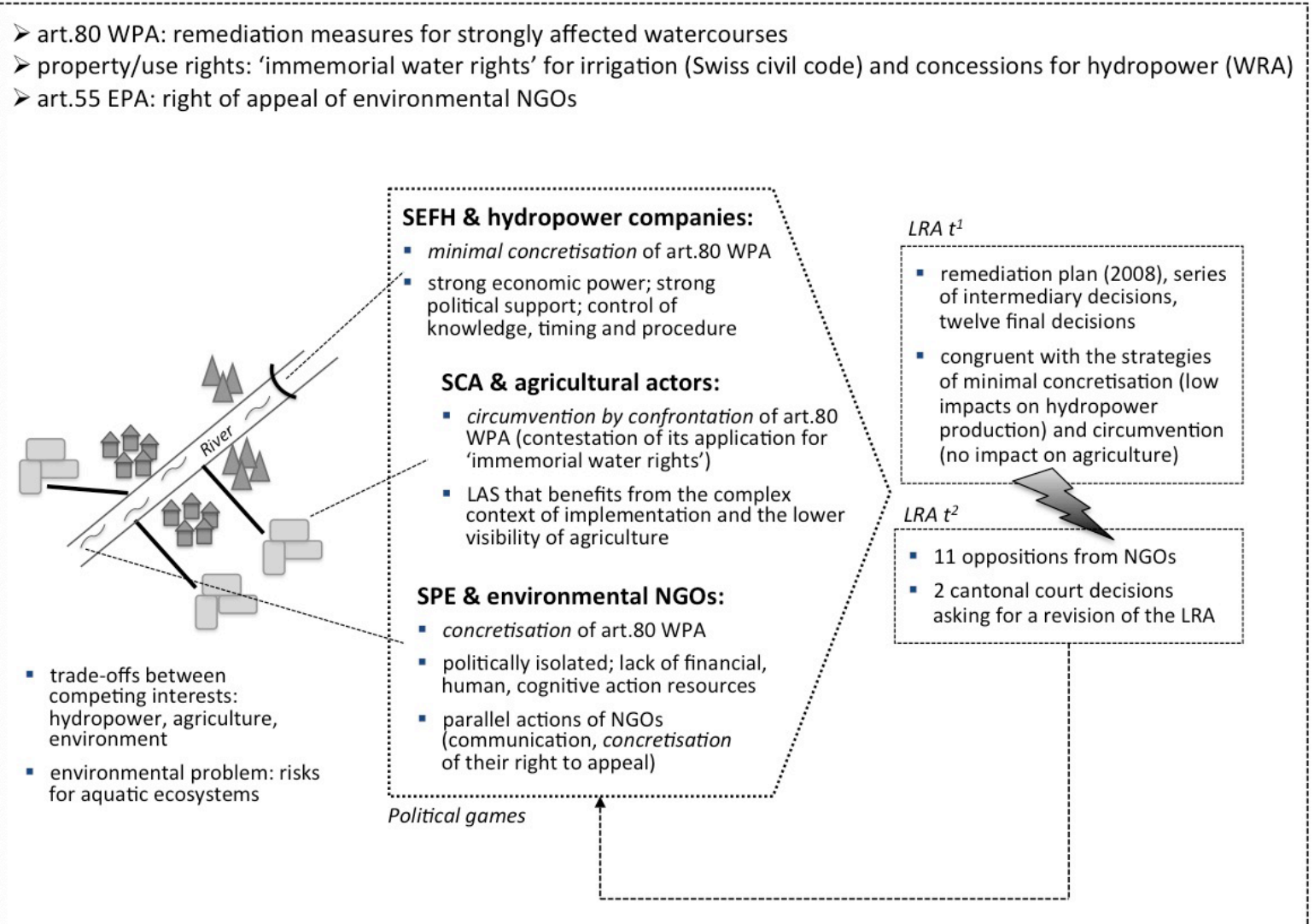

Figure 2 Application of the framework to the case of aquatic ecosystem protection in Valais

cessity to move beyond traditional forms of government by designing more collaborative or flexible policy instruments. As for implementation scholars, their attention would have been on increasing goal compliance by identifying what should have happened and the administrative factors that prevented it from happening. IAD-related approaches, finally, would have provided deductive models of individual decision making and developed principles for a better institutional design.

None of them would have, however, accounted for the strategies adopted by the actors with regards to the rules that structure their action. By drawing attention to this intrinsically political di- mension, the framework developed in the present research complements the three above-mentioned analyses and could inform their recommendations. The case study emphasized, in particular, how the co-action of a complex context of legal rules, on the one hand, and of political interactions between intentional actors, on the other hand, led to the observed (absence of) environmental outcomes. In summary, neither rules (structure) nor actors' actions (agency) appeared, taken independently, sufficient to explain the outcomes of the processes at play. Institutional structures did not impinge on environmental outcomes deterministically, while actors' agency was clearly situated. 
In that respect, LAS proved to be useful mechanisms to investigate "structure in relation to action and action in relation to structure" (Jessop 2001, 1223). In the case under study, the careful identification of LAS revealed how legal rules (the WPA and WRA, but also procedural rules and property right regimes) materialized into actors' interactions. These interactions led to a specific LRA, from which a gap between art. 80 WPA and environmental outcomes emerged. By doing so, LAS allowed to move the notion of institutions from "abstract entities" (Peters $2011,38)$ to more operational constructs coming into life in actors' every-day life. The notion of LAS provided, in sum, an operational typology to make the linkage between legal rules and political behaviors explicit as well as an empirically robust social mechanisms through which the influence of these rules on environmental outcomes is mediated.

Three complementary findings are related to this. The case study highlighted, first, the complex configuration of legal rules that impinged on the course of action. It confirmed the existence of incoherencies among these rules (Gerber et al. 2009), as well as of confrontations in their activation (Aubin 2011) - echoed, in casu, by the strategy of the SCA (activation of immemorial water rights to oppose the concretization of the WPA). Clearly, property rights have to be taken into account when designing policies. The case also underlined the interplay between substantial and procedural rules (Knoepfel et al. 2011), and the central influence of the latter in the concretization of the former. The procedural rule conferring a right to appeal to environmental NGOs (art. 55 EPA) appeared, in particular, as an essential component of the Swiss envi- ronmental policy scheme. The concretization of this rule allowed NGOs to bypass an unfavorable configuration of actors and power distribution to seek for more ambitious environmental outcomes. The reinforcement of such procedural instruments may, thus, appear as a promising path to empower environmental NGOs.

Second, the adoption of a bottom-up orientation stressed the necessity to examine the construction of the problem at the level of action. The analysis showed how the phase of agenda setting that had occurred at the federal level had to be repeated at the cantonal level for collective action to be actually engaged. In other words, the legal recognition of the problem did not mechanically lead to its transposition at the level of action. Quite the opposite, the transposition proved to be particularly disputed, reflecting the contradictions intrinsic to the conduct of public action. Aquatic ecosystem protection involved a wide range of actors, all of them defending presented-as-primordial public interests. These trade-offs fostered instability in the definition of the problem, whose intensity was continually put into question. One of the main concerns for the SPE and the environmental NGOs was, in this context, to reaffirm the importance of the issue with regards to the other public interests at stake. The construction of the problem proved to be, in sum, of high strategic significance.

Finally, the present research confirmed that the game metaphor is a powerful analytical tool to make the actorial driving forces of environmental policymaking explicit. The configuration of actors, power relations, and strategies specific to the canton of Valais-i.e., the three variables inherent to the game imageappeared to be crucial in explaining the 
(absence of) environmental outcomes. Their sound analysis contributed to provide a more nuanced understanding of the processes at play, beyond any forms of de-politicization (Swyngedouw 2009) or institutional determinism (Radaelli, Dente, and Dossi 2012). The game metaphor emphasized the central role of actors' interactions in shaping environmental outcomes and highlighted the predominance of confrontational politics over collaboration or learning. The inter-services working group acted, in particular, more as an arena to produce an apparent consensus around the dominant strategy than as a device of collaboration toward more legitimate environmental outcomes.

\section{Conclusion and future research avenues}

This article focused on the gaps that emerge between legal rules and environmental outcomes. The main analytical claim was to affirm that these gaps would better be seen as the results of political processes, within which actors adopt competing strategies with regards to the rules that structure their action. To that end, the social mechanism of LAS has been developed, embedded within a broader analytical framework, and applied to a case study.

By doing so, the research offers an approach to organize and systematize the analysis of the interplay between legal rules, political behaviors and environmental outcomes. The focus on LAS, rather than ignoring or hiding dynamics of power, contributes to reveal them. Not all actors were, in the case study, equal in the pursuit of their strategy. In the end, a very subtle repertoire of political games was highlighted and the analysis demonstrated how politics never end, and how actors always try to reformulate the modalities of collective action. All in all, the research speaks in favor of a more political and integrative approach to environmental policymaking and provided a promising tool in that goal.

The present paper opens up, however, more avenues for research than it closes. It privileges a general conceptualization to a more parsimonious focus, an illustrative empirical application to a comparative research design. If, by doing so, it makes a generalization potential to most environmental problems plausible, it leaves the question of its application to other policy domains open; if it illustrates the explanatory potential of LAS, it does not allow deducting more specific regularities. It would thus be necessary, in order to strengthen the robustness of the newly developed LAS approach, to conduct more research on this concept. Future research could, for instance, focus on LAS in other highly topical policy sectors such as social, immigration, or energy policies. It could also aim at proposing more deductive research design by testing, for instance, hypotheses on the link between flexibility and implementation or, to the contrary, between rigidity and circumvention. Finally, it would also be interesting to explore LAS in an interdisciplinary perspective, for instance by exploring the sociological and psychological variables that influence the selection of a given LAS.

\section{References}

Adger, Neil W. 2000. "Social and Ecological Resilience: Are They Related?" Progress in Human Geography 24 (3): 347-364. 
Adger, Neil W. et al. 2003. "Governance for Sustainability: Towards a 'Thick' Analysis of Environmental Decisionmaking." Environment and Planning A 35 (6): 1095-1110.

Ansell, Chris, and Alison Gash. 2008. "Collaborative Governance in Theory and Practice." Journal of Public Administration Research and Theory 18 (4): 543-571.

Aubin, David. 2008. "Asserted Rights: Rule Activation Strategies in Water User Rivalries in Belgium and Switzerland. " Journal of Public Policy 28 (2): 207-227.

Aubin, David. 2011. "Non-Owners' Success: Confrontations of Rules in Rivalries Between Water Users in Belgium and Switzerland." Environmental Politics 20 (2): 210-226.

Bachrach, Peter, and Moron S. Baratz. 1963. "Decisions and Nondecisions: An Analytical Framework." The American Political Science Review 57 (3): 632-642.

Bäckstrand, Karin, Jamil Khan, Annica Kronsell, and Eva Lövbrand. 2010. Environmental Politics and Deliberative Democracy. Examining the Promise of New Modes of Governance. Cheltenham: Edward Edgar.

Bardach, Eugene. 1977. The Implementation Game: What Happens after a Bill Becomes Law. Cambridge: MIT Press.

Barrett, Susan M. 2004. "Implementation Studies: Time for a Revival? Personal Reflections on 20 years of Implementation Studies." Public Administration 82 (2): 249-262.

Barrett, Susan M., and Colin Fudge. 1981. Policy and Action: Essays on the Implementation of Public Policy. London: Methuen.
Berthelot, Jean-Michel. 1990. L'intelligence du Social. Paris: Presses Universitaires de France.

Bourdieu, Pierre. 1986. "Habitus, Code et Codification." Actes de la Recherche en Sciences Sociales 64: 40-44.

Bourdieu, Pierre. 1990. "Droit et PasseDroit." Actes de la Recherche en Sciences Sociales 81: 86-96.

Carlsson, Lars G., and Annica C. Sandström. 2008. "Network Governance of the Commons." International Journal of the Commons 2 (1): 33-54.

Clement, Floriane. 2010. "Analysing Decentralised Natural Resource Governance: Proposition for a "Politicised" Institutional Analysis and Development Framework." Policy Sciences 43 (2): 129156.

Crozier, Michel, and Erhard Friedberg. 1977. Lacteur et le Système. Paris: Editions du Seuil.

deLeon, Peter. 1994. "Reinventing the Policy Sciences: Three Steps Back to the Future." Policy Sciences 27 (1): 77-95.

deLeon, Peter, and Linda deLeon. 2002. "What Ever Happened to Policy Implementation? An Alternative Approach." Journal of Public Administration Research and Theory 12 (4): 467-492.

Dunsire, Andrew. 1978. Implementation in a Bureaucracy. The Execution Process. Oxford: Martin Robertson.

Dupuis, Johann and Peter Knoepfel. 2015. The Politics of Contaminated Sites Man- 
agement: Institutional Regime Change and Actors' Mode of Participation in the Environmental Management of the Bonfol Chemical Waste Landfill in Switzerland. Dodrecht: Springer.

Federal Council. 1987. Message Concernant l'Initiative Populaire 'Pour la Sauvegarde de nos Eaux' et la Révision de la Loi Fédérale sur la Protection des Eaux. Berne: Federal Council.

Federal Office for Agriculture. 2007. Etat de l'Irrigation en Suisse - Bilan del'Enquête 2006. Berne: OFAG.

Federal Office for the Environment. 2013. Assainissement des débits résiduels au sens de l'art. 80ss, LEaux: état à fin 2012 et évolution depuis le second semestre 2011. Berne: OFEV.

Gerber, Jean-David, Peter Knoepfel, Stéphane Nahrath, and Frédéric Varone. 2009. "Institutional Resource Regimes: Towards Sustainability Through the Combination of Property-Rights Theory and Policy Analysis." Ecological Economics 68 (3): 798-809.

Gleick, Peter H., Heather Cooley, Michael J. Cohen, Mari Morikawa, Jason Morrison, and Meena Palaniappan. 2009. The World's Water 2008-2009: The Biennial Report on Freshwater Resources. Washington: Island Press.

Hajer, Maarten, and Hendrik Wanegaar. 2003. "Introduction". in Deliberative Policy Analysis. Understanding Governance in the Network Society, eds. Maarten Hajer, and Hendrik Wanegaar. Cambridge: University Press, 1-33.
Hall, Peter A. 2008. "Systematic Process Analysis: When and How to Use It." European Political Science 7 (3): 304-317.

Hargrove, Erwin C. 1975. The Missing Link: The Study of the Implementation of Social Policy. Washington D.C.: The Urban Institute.

Hay, Colin. 2002. Political Analysis: A Critical Introduction. Basingstoke: Palgrave Macmillan.

Hedström, Peter, and Petri Ylikoski. 2010. "Causal Mechanisms in the Social Sciences." Annual Review of Sociology 36: 49-67.

Hill, Michael, and Peter Hupe. 2014. Implementing Public Policies. London: Sage.

Hjern, Benny, and Chris Hull. 1982. "Implementation Research as Empirical Constitutionalism." European Journal of Political Research 10 (2): 105-115.

Hornborg, Alf. 2009. "Zero-Sum World: Challenges in Conceptualizing Environmental Load Displacement and Ecologically Unequal Exchange in the World-System." International Journal of Comparative Sociology 50 (3-4): 237-262.

Hupe, Peter. 2011. "The Thesis of Incongruent Implementation: Revisiting Pressman and Wildavsky." Public Policy and Administration 26 (1): 63-80.

Hupe, Peter. 2014. "What Happens on the Ground: Persistent Issues in Implementation Research." Public Policy and Administration 29 (2): 164-182.

IPCC. 2014. "Climate Change 2014: Synthesis Report." Contribution of Working 
Groups I, II and III to the Fifth Assessment Report of the Intergovernmental Panel on Climate Change, Geneva.

Ingram, Helen. 1990. "Implementation: A Review and Suggested Framework." In Public Administration: The State of the Field, eds. Naomi B. Lynn, and Aaron B. Wildavsky. Chatham: Chatham House Publishers.

Jessop, Bob. 2001. "Institutional Re(turns) and the Strategic-relational Approach." Environment and Planning A 33 (7): 12131235.

Johnson, Craig. 2004. "Uncommon Ground: The 'Poverty of History' in Common Property Discourse." Development and Change 35 (3): 407-433.

Jordan, Andrew, and Dave Huitema. 2014. "Innovations in Climate Policy: the Politics of Invention, Diffusion, and Evaluation." Environmental Politics 23 (5): 715734.

Jordan, Andrew, Rüdiger K.W. Wurzel, and Anthony Zito. 2003. ''New' Instruments of Environmental Governance: Patterns and Pathways of Change." Environmental Politics 12 (1): 1-24.

Kemp, René, Derk Loorbach, and Jan Rotmans. 2007. "Transition Management as a Model for Managing Processes of Co-evolution towards Sustainable Development." International Journal of Sustainable Development and World Ecology 14 (1): 78-91.

Kenis, Anneleen, and Matthias Lievens. 2014. "Searching for 'the Political' in Environmental Politics." Environmental Politics 23 (4): 531-548.
Korpi, Walter. 1985. "Power Resources Approach vs. Action and Conflict: On Causal and Intentional Explanations in the Study of Power." Sociological Theory 3 (2): 31-45.

Knoepfel, Peter. 1992. "Environmental Policy." In Encyclopedia of Government and Politics, eds. Mary Hawkesworth, and Maurice Kogan, vol. 2. London and New York: Routledge.

Knoepfel, Peter, Corinne Larrue, Frederic Varone, and Michael Hill. 2011. Public Policy Analysis. Bristol: The Policy Press.

Lamaison, Pierre, and Pierre Bourdieu. 1986. "From Rules to Strategies: an Interview with Pierre Bourdieu." Cultural Anthropology 1 (1): 110-120.

Largey, Thierry. 2013. "L'Assainissement des Cours d'Eau dans l'Application de l'art.80 LEaux-Les Enseignements de l'Arrêt Misoxer Kraftwerke." Droit de l'environnement dans la Pratique 2: 92-113.

Lascoumes, Pierre. 1990. "Normes Juridiques et Mise en Euvre des Politiques Publiques." Année Sociologique, 40: 43-71.

Lemos, Maria C., and Arun Agrawal. 2006. "Environmental Governance." Annual Review of Environmental Resource 31: 297-325.

Levin, Kelly, Benjamin Cashore, Steven Bernstein, and Graeme Auld. 2012. "Overcoming the Tragedy of Super Wicked Problems: Constraining our Future Selves to Ameliorate Global Climate Change." Policy Sciences 45 (2): 123-152.

Lubell, Mark. 2013. "Governing Institutional Complexity: The Ecology of Games 
Framework." Policy Studies Journal 41 (3): 537-559.

Moe, Terry M. 2005. "Power and Political Institutions." Perspective on Politics 3 (2): 215-233.

Offe, Claus. 2009. "Governance: An 'Empty Signifier'?" Constellations 16 (4): 550-562.

Olsson, Per, Carl Folke, and Thomas Hahn. 2004. "Social-ecological Transformation for Ecosystem Management: The Development of Adaptive Co-management of a Wetland Landscape in Southern Sweden." Ecology and Society 9 (4). www. ecologyandsociety.org/vol9/iss4/art2/.

Ostrom, Elinor. 2007a. "Institutional Rational Choice: An Assessment of the Institutional Analysis and Development Framework." In Theories of the Policy Process, ed Paul A. Sabatier. Boulder: Westview Press.

Ostrom, Elinor. 2007b. "A Diagnostic Approach for Going beyond Panaceas." Proceedings of the National Academy of Sciences 104 (39): 15181-15187.

Palumbo, Dennis J., and Donald J. Calista. 1990. "Opening Up the Black Box: Implementation and the Policy Process." In Implementation and the Policy Process. Opening up the Black Box, eds. Dennis J. Palumbo, and Donald J. Calista. Westport: Greenwood Press, 3-18.

Patton, Michael Q. 1990. Qualitative Evaluation and Research Methods. Newbury Park: Sage Publications.

Peters, B. Guy. 2011. Institutional Theory in Political Science: The 'New Institutional- ism'. London and New York: Pinter.

Pressman, Jeffrey, and Aaron Wildavsky. 1973. Implementation. Berkeley: UC Press.

Radaelli, Claudio, Bruno Dente, and Samuele Dossi. 2012. "Recasting Institutionalism: Institutional Analysis and Public Policy." European Political Science 11 (4): 537-550.

Ragin, Charles C. 2000. Fuzzy-Set Social Science. Chicago: University of Chicago Press.

Rhodes, Roderick A.H. 1997. Understanding Governance. Milton Keynes: Open University Press.

Robichau, Robbie W., and Laurence E. Lynn. Jr. 2009. "The Implementation of Public Policy. Still the Missing Link." The Policy Studies Journal 37 (1): 21-36.

Scharpf, Fritz. 1997. Games Real Actors Play: Actor-Centered Institutionalism in Policy Research. Oxford: Westview Press.

Schlager, Edella, and Elinor Ostrom. 1992. "Property-Rights Regimes and Natural Resources: A Conceptual Analysis." Land Economics 68 (3): 249-262.

Schofield, Jill. 2001. “Time for a Revival? Public Policy Implementation: A Review of the Literature and an Agenda for Future Research." International Journal of Management Reviews 3 (3): 245-263.

Schweizer, Rémi. 2013. "Accessibility, Equity and the Sharing of Water Resources: A Critical Analysis of Community Governance Models based on a Case Study of the Irrigation Channels of the Valais." 
Journal of Alpine Research 101 (3). https:// rga.revues.org/2238.

Sondershaus, Franck, and Timothy Moss. 2014. "Your Resilience is My Vulnerability: 'Rules in Use' in a Local Water Conflict." Social Sciences 3 (1): 172-192.

Stoker, Gerry. 1998. "Governance as Theory: Five Propositions." International Social Science Journal 50 (155): 17-28.

Swyngedouw, Erik. 2009. "The Antinomies of the Postpolitical City: In Search of a Democratic Politics of Environmental Production." International Journal of Urban and Regional Research 33 (3): 601-620.

Torgerson, Doug. 1986. "Between Knowledge and Politics: Three Faces of Policy Analysis." Policy Sciences 19 (1): 33-59. Varone, Frederic, Stéphane Nahrath, David Aubin, and Jean-David Gerber. 2013. "Functional regulatory spaces." Policy Sciences 46 (4): 311-333.

Voss, Jan-Peter, and Basil Bornemann. 2011. "The Politics of Reflexive Governance: Challenges for Designing Adaptive Management and Transition Management." Ecology \& Society 16 (2). www. ecologyandsociety.org/vol16/iss2/art9/.

Wagenaar, Hendrik. 2015. “The Political Process of Policymaking. A Pragmatic Approach to Public Policy, by Philippe Zittoun." Critical Policy Studies 9 (2): 248251.

Winter, Soeren. 2012. "Implementation Perspectives: Status and Reconsideration." In Handbook of Public Administration, eds. B. Guy Peters, and Jon Pierre. London: Sage, 265-291.

\section{Acknowledgments}

I would like to thank Oriane Sarrasin, the two anonymous reviewers, and the members of the research group "Resources and Institutional Regimes" for their contributions to this paper. The realization of this research was supported by the Swiss National Science Foundation (snf) under Grant number 406140_125900. 